\title{
STUDENT E-BOOKS CONFIDENCE AND MOBILE SYSTEM OWNERSHIP
}

\author{
Queen E. Booker, Minnesota State University, Mankato, queen.booker@mnsu.edu
}

\begin{abstract}
Use of computers as an educational tool has risen significantly in higher education. A 2007 study by Educause shows that students are engaged in the use of technology for the purpose of learning. According to the study the majority of students liked learning through Internet searches, video games and simulations-all tools used in courses engaged with innovative learning. More recently mobile devices such as laptops, PDAs and cell phones have become essential tools for students, allowing them to access learning management systems and other college or university related resources in a "just-in-time" manner. But many courses still use the book as the primary learning tool. This exploratory study examines the attitudes of students owning mobile devices towards e-books as a response to the rapid increase in the use of electronic books as an alternative to traditional books at the college level. The results find that with the growth in owning and using mobile devices, student attitudes towards electronic books as a learning tool trended upwards. This information is helpful as colleges and universities continue to look towards ebooks as one method of reducing the cost of instruction.
\end{abstract}

Keywords: Mobile computing, Attitudes, Human-Computer Interaction

\section{INTRODUCTION}

The use of computers has become an integral part of education; its reputation as being a tool for the innovative learning environment as well as its impact on teaching and learning is widely accepted [21, 15]. The introduction of smaller wireless-ready computers has basically transformed what can be done in the classroom. No longer are professors limited to computer based tasks in the classrooms when students can bring in laptops, PDA's and smart phones into the classroom. With appropriate wireless access, an instructor can engage students with Internet based or interactive activities that require use of mobile technologies. To the same extent, when instructors make content available via the Internet, students can access course content anywhere at any time, creating flexibility in access to education. As educational institutions move toward a greater use of Internet based technologies, it follows that ebooks would also be a part of that migration. In fact, a November 14, 2010 Chronicle of Higher Education lead story began as follows: "As students cut costs by buying books from cheaper online retailers or by downloading etextbooks, campus bookstores sell fewer and fewer textbooks. The story continues with "[s]ales of e-textbooks have recently risen, and some see that as a sign that digital will soon replace print. But some are convinced that the trend is driven by price rather than students' desire to give up physical books. "What I hear more than 'I want digital' is 'I want a better price,"' one book store manager says."[23] These questions are important to higher education because there is continual pressure on faculty to engage in the use of technology and to use electronic textbooks to reduce the cost of attendance. Even in Mr. Young's article he refers to physical textbooks as "old fashioned." The Prentice Hall web site for educators even states, "eTextbooks save time and money.... Reduce time, cost, and environmental impact.... offer your students up to 50\% savings over the printed text." These incentives do make electronic textbooks seem like the perfect solution in a digital world. However, a recent study showed that there is a correlation between socio-economic background and student acceptance of e-books as a learning tool [2]. The study included data from 2007 through 2009 and showed that there was an increase in acceptance from 2007 to 2009 but there was a significant gap in acceptance growth based on socio-economic background. The study showed that there is a correlation but not necessarily a causal effect. So, while income alone cannot determine a student's confidence in the use of technology for learning, it may possibly be a factor. Other potential factors could be not necessarily comfort with computers in general but comfort with mobile technologies. For example, a student using an e-book on a laptop can carry the book with them at all times because of the mobility of the laptop or smartphone. But a student using an e-book on a desktop is limited to its use by having to access a computer, even if the e-book is accessible from the Internet. This study uses data from the Booker and Kitchens [2] study to examine the attitudes towards traditional books and e-books of students who use mobile technologies. 
Volume XII, No. 2, pp 201-206, 2011

\section{BACKGROUND}

Prior research suggests that the use of computers has become an integral part of education and its impact on teaching and learning is widely accepted [21, 15], although the successful integration of computers in educational environments depends to a great extent on students' attitudes towards them [8,17]. That is, educational technology is only successful if the person using it is confident in its use. Thus, in order for electronic books to effectively replace "old fashioned" textbooks, students must be comfortable using them. Computer attitude is been defined as "a person's general evaluation or feeling of favor or antipathy towards computer technologies and specific computerrelated activities" [19]. Several variables have been associated with computer attitude including but not limited to, user confidence, perceived importance of the computer, perceived usefulness of the computer and ease of use of the computer. [22] These variables tend to measure people's attitudes in general. For faculty, an additional desired goal may be for students to perceive the use of the computer as an educational tool or a tool for learning, much the same way books are perceived [6]. By extension, if students are becoming more comfortable with computers, and are confident in using computers for learning, then an assumption can be made that students should also become more confident about using electronic books, which are a combination of physical books and computers, for learning.

There have been several studies examining attitudes towards books and computers. The most recent was the 2011 study by Booker, Kitchens and Harris [3] which found that despite the continued growth in online learning technologies and other supplemental digital learning environments; student attitudes towards books and computers, as measured by separate but matched scales, were basically equal. There were also indications that students had a higher attitude towards computers than for books as a preference for learning. However, this study focused primarily on comparing student attitudes towards books and computers for learning, not specifically electronic books. A 2011 study by Booker and Kitchens [2] found that there is a correlation between socio-economic factors and attitudes towards e-books.

Gardner, Dukes \& Discenza [6] and Caruso et al [5] studied computers as a learning tool. Gardner et al found that 'computer confidence positively affected computer attitudes' in a large group of primary level students. Caruso produced a study for Educause that showed the tremendous growth in the ownership of technology by students as well as their perceptions of use of computers as a learning tool. They found that $60.9 \%$ of students felt that using computers improved their learning. They also found that almost $99 \%$ of students owned some type of computer (laptop, desktop, smartphone) and used it for learning even if it was as limited as participating in an online discussion forum on Facebook or searching the Internet for information.

There have been prior studies on student attitudes towards electronic books (see 9, 10,11, 13). Research has found small to moderate relationships between computer confidence and computer attitudes [19] and between experience, use, and confidence levels [14]. Recent studies by Garland and Noyes [8, 7] concluded that though students rated computers high as a learning tool, the difference was not significant from that of books as a learning tool. In addition, prior research has shown that socioeconomic status has an effect on educational achievement. Researchers have examined academic achievements in relation to socioeconomic background and have found mixed results ranging from a strong relation [12, 20] to no significant correlation at all [18]. Specific to socioeconomic status (SES) and technology, Attewell and Battle [1] found that children from high SES homes achieve greater educational gains from home computers than do children from lower SES homes. However, the literature itself is not extensive in regards to SES and college aged students.

This study is contributes to the education and learning literature by examining student with access to and use of mobile technologies' confidence in electronic books as learning tools based on longitudinal data.

\section{METHODOLOGY}

The study used archived data from the Booker, Kitchens and Harris [3] study. Their study involved data collected using an online survey developed on surveymonkey.com. The overall survey was a slightly modified version of the Books and Computers Questionnaire (BAC) developed by Garland et al [6] which is based on an earlier instrument by Levine \& Donitsa-Schmidt [14] to examine both book and computer attitudes. Four questions were eliminated from the Garland et al instrument due their subjectivity of interpretation leaving sixteen matched questions. This 
survey was chosen because the prior use of the scale [7] had demonstrated a reasonable level of reliability. Following the Garland and Noyes study, the responses for the base questions provided were in the form of a 5-point Likert scale ('strongly agree' to 'strongly disagree'). Respondents were also asked demographic information such as age, ethnicity, and gender; and socioeconomic data such as parental income, parental education, parental job type (white collar / blue collar) and parental marital status. They were also asked to rate their levels of confidence with computers in general as well as whether or not they owned a computer, a laptop, a cellphone, and/or another mobile device. Students were also asked about their confidence for learning with computers, books, and electronic books, how much time the computer was used for school and how much time the computer was used for other purposes.

The main question examined for the current study was confidence in using electronic books for learning. Descriptive data used for the analysis were year $(2007,2008,2009)$ and mobile device ownership.

There were 7,518 usable responses collected from 2007 through 2009 of which forty nine percent were from females, seventy-five percent were from white Americans, and fifty-two percent were from students whose parents' incomes were above the national median for the respective year. The gender, ethnicity, and income percentages are consistent with the post-secondary enrollments reported by U. S. Department of Education study [16]. Fifty-one percent of the respondents were traditional aged college students, i.e., 18-23. Of the 7,518 responses, 5,408 owned at least one type of mobile device.

\section{Hypotheses}

The main research question for this study was, "is there a difference in confidence among college students in using electronic books based on mobile device ownership?" So the hypothesis was as follows:

H1. Students owning at least one mobile device would show significantly more confidence in using electronic books.

This hypothesis is based on the increased access to electronic books and the improvement in wireless access. Since 2007, Google Books has become a true online library making many general books accessible to the public for free. There are a limited number of textbooks that are available for free but the options have significantly increased since 2007. [4] Further, the higher education textbook manufacturers have made more titles accessible as electronic texts. Specific tools have been produced for reading electronic books such as the Nook and Kindle, notwithstanding institutions giving students the option of using electronic books as a mechanism for reducing costs. Nevertheless, as a mainstream product, electronic books are a fairly new phenomenon. Although the first documented electronic book was introduced in 1971, most of the early uses were to use technology to make classics accessible to a wider audience. Thus is it reasonable to presume that the use of electronic books would not be as widely adopted at the college level in 2007 as it is in 2009, making it likely that the confidence in using such electronic books would not be high simply due to lack of or limited exposure to electronic books for the purpose of learning.

\section{Data Analysis}

The data was analyzed in two steps. The first step was to generate the descriptive statistics for the data used to test the main research question and the second step was to test the hypothesis. For each question, the most positive answer was "5" and the least positive was " 1 . Descriptive statistics were generated for the following four questions:

- How at ease do you feel using a computer?

- How confident do you feel about using computers for learning?

- How confident do you feel about using physical books for learning?

- How confident do you feel about using electronic books for learning?

The means for the responses were generated for each year. The means were average, roughly 3 (neutral) with a standard deviation of about 1.43 for the first three questions which suggests that overall the responses did not deviate from year to year. The means for the fourth question, however, increased from 2.70 in 2007 to 2.79 in 2008 and 3.08 in 2009. However, the standard deviation for the last question was roughly 1.10 indicating less variability 
in the responses to the question. A graphic of the means by year and by question are shown in Figure 1 shown on the next page.

Note that the confidence in using electronic books grew between 2007 and 2009 whereas the ease of using computers decreased. Based on the data collected this is partially explained by the increase in the percentage of students who responded that they used simulations and learning management systems in 2008 and 2009.

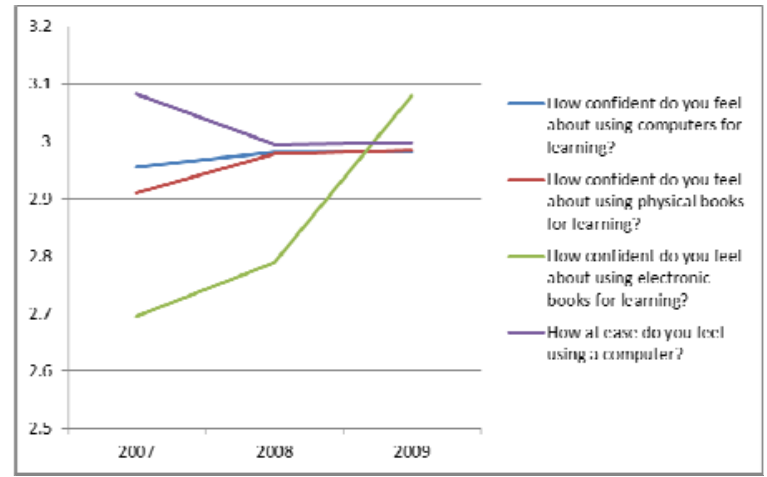

Figure 1. Means By Year for Key Questions

Figure 2 shows the means for each question broken down by whether or not the student owned any type of mobile device. This grouping includes whether the student owned a pager, nook, iPad, laptop, etc. The graph implies that when separated for analysis, students owning mobile devices decreased their confidence in learning from books than students who did not own mobile devices. Both groups, however, increased their confidence in learning from ebooks.

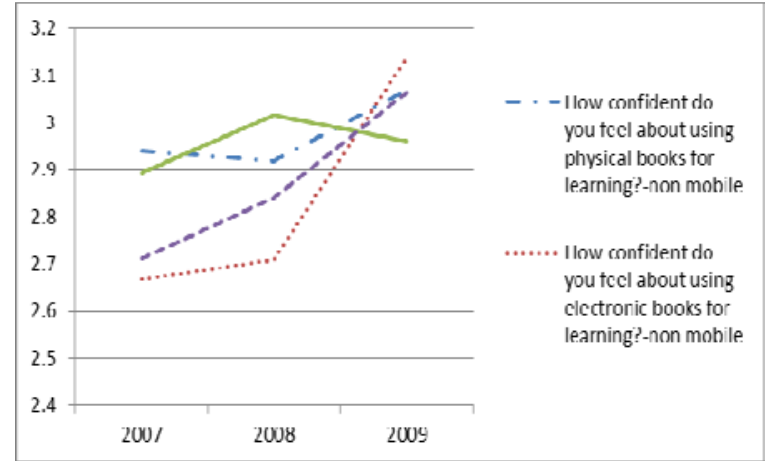

Figure 2. Breakdown by year and whether or not the student owned mobile devices

\section{RESULTS}

The next step was to test the hypothesis. Recall the hypothesis:

H1. Students owning at least one mobile device would show significantly more confidence in using electronic books than students who did not own a mobile device.

The overall means for students owning mobile devices was 2.97 as compared to 2.89 for students who did not own mobile devices. But the question remains if the difference is significant. To test the differences, Wilcoxon rank-sum test was used. The analysis was to test the differences in confidence between the mobile and non-mobile owners. The results were significant at $\mathrm{p}<0.05$. Based on the test results, the hypothesis is not rejected. 
Volume XII, No. 2, pp 201-206, 2011

\section{CONCLUSIONS}

This study is part of an on-going analysis of the acceptance and confidence of students using e-books as a learning tool as educational institutions move towards the digital format as a cost saving and efficient way of providing reading material to students. While this particular study focused only on confidence and mobile technologies, there are deeper analyses that must be made to effectively use data regarding electronic books. For example, within this dataset, when business program students are compared with non-business program students, there is a significant difference in the means for computer attitudes and book attitudes regardless of learning environment, ownership of mobile technology and/or year. Preliminary results also suggest that younger students in 2009 rated computers more positively than books overall, and even more so for the above four question pairs. Also, as time spent on the computer for activities other than school increases, the more positive the score becomes for computers than books. Thus, further analysis needs to be done by age, gender, ethnicity, frequency of use of computer, comfort level and if the student is enrolled part-time or full time. Gregory [12] found that $66 \%$ of the students in her survey preferred ebooks to regular books. This is consistent with our findings but we also found that students who owned cell phones but not laptops were not as confident in using e-books as students who owned laptops. This is understandable in that the screens on cell phones are not as large as those on laptops or e-book readers. This study is an on-going process. 2010 data is being coded and 2011 data is being collected.

But this is just a first step. This study only confirms that there is a difference but does not attempt to explain why the difference exists. The dataset contains a plethora of data that can help explain some of the differences beyond mobile ownership. Further studies will be completed using regression analysis to examine the impact of gender, ethnicity, level in college, age, parental educational attainment, parental marital status, type of educational environment by both type of college (private or public) and technological level of the college or program. Finally specific questions regarding attitudes towards computers and books in general were collected and can also be used to help explain some of the difference. In addition to further analysis, the research team is continuing to collect data from the institutions with the goal of increasing participation from other institutions to generate results that may be more generalizable.

\section{REFERENCES}

1. Attewell, P. \& and Battle, J. (1999) "Home computers and school performance. In Information Society," vol. 15.

2. Booker, Q. \& Kitchens, F., (2011). An Exploratory Study of Student Confidence in Using Electronic Books as Learning Tools, 2011 IEEE Technology and Society Syposium.

3. Booker, Q., Kitchens, F., \& Harris, T. (2011). An Exploratory Study of the Impact of Innovation Education on Student Attitudes toward Books and Computers as Learning, 2011 Southwest Decision Sciences Institute Conference, March 2011.

4. Brin, S. \& Page, L. History of Google Books (last updated 2010). http://books.google.com/googlebooks/history.html accessed November 19, 2010

5. Caruso, J. \& Salaway, G. (2007) "The E-CAR study of undergraduate students and information technology," available at http://net.educause.edu/ir/library/pdf/ERS0706/ecm0706.pdf.

6. Gardner, D. G., Dukes, R. L. \& Discenza, R. (1993). Computer use, self-confidence, and attitudes: a causal analysis. Computers in Human Behavior, 9, 427-440.

7. Garland, K. J. \& Noyes, J. M. (2004). Computer Experience: A poor predictor of computer attitudes. Computers in Human Behavior, 20, 823-840.

8. Garland, K. \& Noyes, J. (2005) Attitudes and confidence towards computers and books as learning tools: a cross-sectional study of student cohorts, British Journal of Educational Technology. 36:1 pp 85-91

9. Gregory, C. (2008) "But I Want a Real Book": An Investigation of Undergraduates Usage and Attitudes toward Electronic Books. Reference \& User Services Quarterly. 47:3, pp 266-273,

10. Hannon, E. (2008) "E-texts in the classroom," in EDUCAUSE Quarterly, vol. 7, pp. 12-13. Available at: http://connect.educause. edu/Library/EDUCAUSE+Quarterly/ETextsintheClassroom/46026 (accessed October 17, 2010).

11. Hartley,A. (2008) "The future of the E-book outlined: Latest research concludes - make it more BOOK-like!," at Tech Radar.com, Available at: http://www.techradar.com/news/world -of-tech/the-future-of-the-bookoutlined-409734 (accessed October 17, 2010). 
12. Lamdin, D. J. (1996) "Evidence of student attendance as an independent variable in education production functions," in Journal of Educational Research, vol. 89, pp. 155-162.

13. Lewis, S. "E-book discovery and use behaviour is complex," in Evidence Based Library and Information Practice, vol. 3, pp. 38-41, 2008

14. Levine, T. \& Donitsa-Schmidt, S. (1998). Computer use, confidence, attitudes and knowledge: a causal analysis. Computers in Human Behavior, 14. pp 125-146.

15. Mitra, A., Lenzmeier, S., Steffensmeier, T., Avon, R., Qu, N. \& Hazen, M. (2000). Gender and computer use in an academic institution: report from a longitudinal study. Journal of Education Computing Research, 23, 1, 6784.

16. http://nces.ed.gov/das/epubs/showTable2004.asp?rt=p\&tableID=1629

17. Palaigeorgiou, G. E., Siozos, P. D., Konstantakis, N. I. \& Tsoukalas, I. A. (2005). A computer attitude scale for computer science freshmen and its educational implications. Journal of Computer Assisted Learning, 21, 330342.

18. Ripple, C. H. \& Luthar, S. S. (2000) "Academic risk among inner-city adolescents: The role of personal attributes," in Journal of School Psychology, vol. 38, pp. 277-298.

19. Smith, B., Caputi, P., Crittenden, N., Jayasuriya, R. \& Rawstorne, P. (1999). A review of the construct of computer experience. Computers in Human Behavior, 15, pp 227-242.

20. Sutton, A. \& Soderstrom, I., (1999) "Predicting elementary and secondary school achievement with schoolrelated and demographic factors," in Journal of Educational Research, vol. 92, pp. 330-338.

21. Teo, T. (2008) Assessing the computer attitudes of students: An Asian perspective. Computers in Human Behavior, 24, 4, pp 1634-1642

22. Woodrow, J. E. J. (1994). The development of computer-related attitudes of secondary students. Journal of Educational Computing Research, 11, 307-338.

23. Young, J. (2010) “Wired Campus,” in Chronicle of Higher Education, November 14, 2010 